
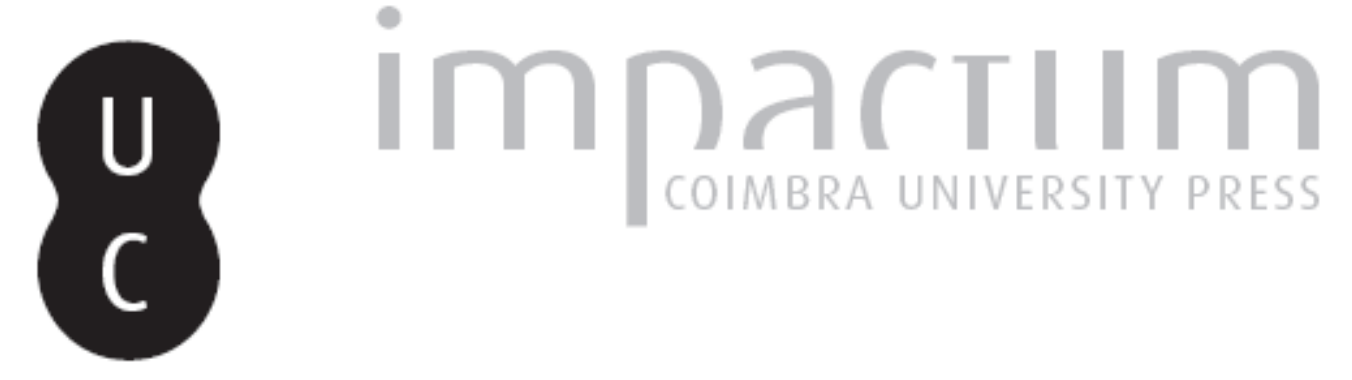

\title{
O arcebispo de Braga, D. Frei Bartolomeu dos Mártires (1559-82): um caso de inquisição pastoral?
}

Autor(es): $\quad$ Marcocci, Giuseppe

Publicado por: Centro de História da Sociedade e da Cultura

URL persistente:

URI:http://hdl.handle.net/10316.2/39579

DOI:

DOI:http://dx.doi.org/10.14195/1645-2259_9_4

Accessed : $\quad$ 26-Apr-2023 14:34:33

A navegação consulta e descarregamento dos títulos inseridos nas Bibliotecas Digitais UC Digitalis, UC Pombalina e UC Impactum, pressupõem a aceitação plena e sem reservas dos Termos e Condições de Uso destas Bibliotecas Digitais, disponíveis em https://digitalis.uc.pt/pt-pt/termos.

Conforme exposto nos referidos Termos e Condições de Uso, o descarregamento de títulos de acesso restrito requer uma licença válida de autorização devendo o utilizador aceder ao(s) documento(s) a partir de um endereço de IP da instituição detentora da supramencionada licença.

Ao utilizador é apenas permitido o descarregamento para uso pessoal, pelo que o emprego do(s) título(s) descarregado(s) para outro fim, designadamente comercial, carece de autorização do respetivo autor ou editor da obra.

Na medida em que todas as obras da UC Digitalis se encontram protegidas pelo Código do Direito de Autor e Direitos Conexos e demais legislação aplicável, toda a cópia, parcial ou total, deste documento, nos casos em que é legalmente admitida, deverá conter ou fazer-se acompanhar por este aviso.

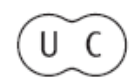



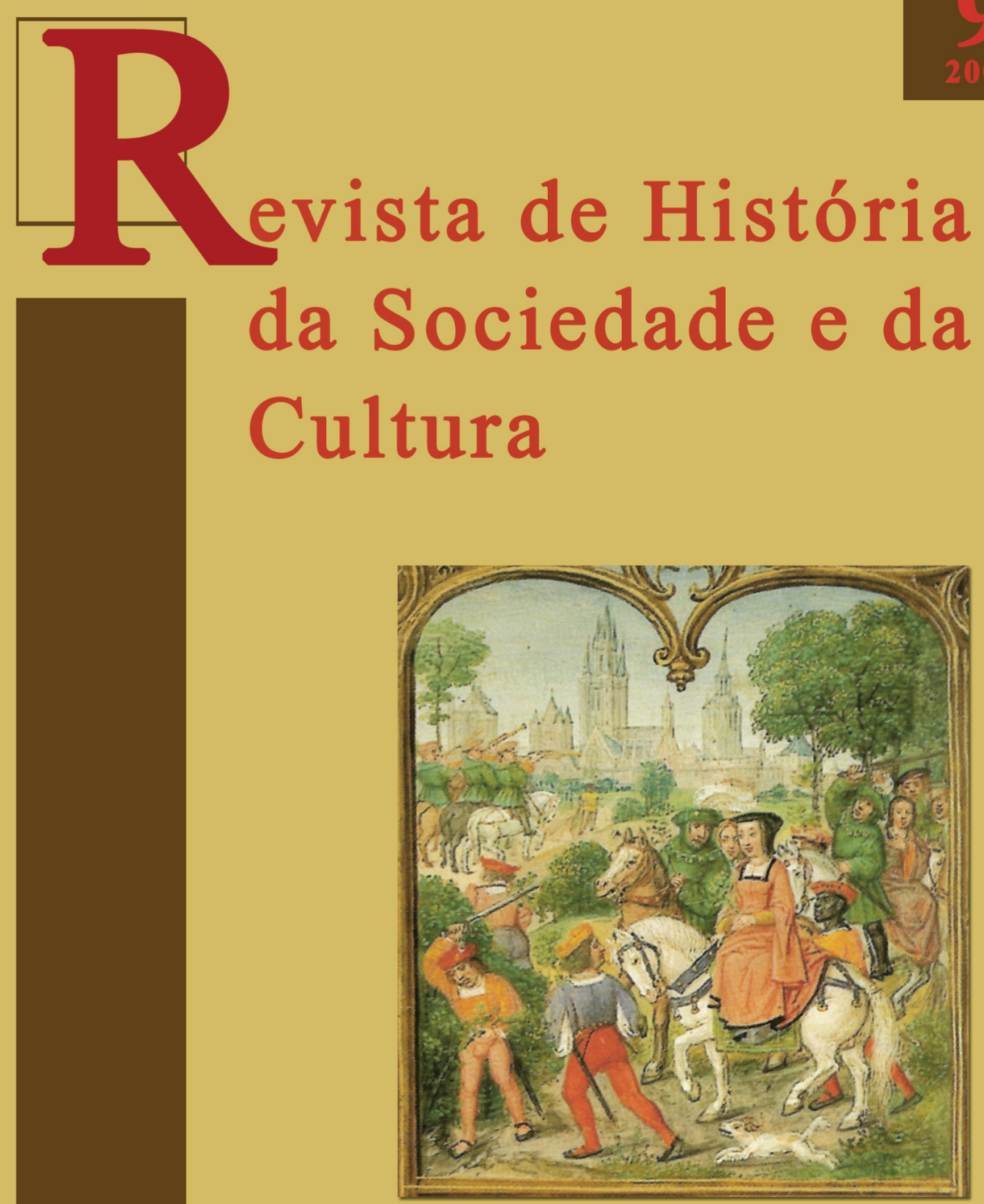

Centro de História da Sociedade e da Cultura Universidade de Coimbra

Coimbra 


\title{
O arcebispo de Braga, D. Frei Bartolomeu dos Mártires (1559-82). Um caso de inquisição pastoral?
}

\author{
Giuseppe Marcocci \\ Scuola Normale Superiore, Pisa \\ g.marcocci@sns.it
}

Texto entregue em/Text submited on: 06/04/2009

\begin{abstract}
Resumo/Abstract:
As relações entre os bispos e os inquisidores têm sido um assunto central na recente historiografia sobre a justiça eclesiástica no mundo católico da Idade Moderna. A correcta imagem de uma geral colaboração entre os dois poderes em Portugal não deve obliterar o conhecimento histórico dos percursos concretos que produziram esse equilíbrio. Na altura em que D. frei Bartolomeu dos Mártires era arcebispo de Braga (1559-82), a Inquisição portuguesa actuou de forma extremamente limitada no território da arquidiocese, sobretudo em comparação com outras dioceses do Norte. O presente estudo de caso pretende oferecer uma hipótese explicativa para esta situação, à luz da cultura teológica do arcebispo bracarense, da sua posição na hierarquia política e religiosa do Reino e dos poucos vestígios do uso de um modelo de vigilância sobre a heresia capilar e eficaz, mas alternativo ao do Santo Ofício: a "inquisição pastoral".

Relations between bishops and the Inquisiton have been the subject-matter of recent historiography on ecclesiastical justice in the Early Modern Catholic world. The exact image of a general cooperation between these two powers in Portugal may not obliterate the historical knowledge of the concrete tracks that produced such a balance. When Friar Bartolomeu dos Mártires was Archbishop of Braga (1559-82), the Portuguese Inquisition enjoyed limited power in this archdiocese, particularly when compared to the other dioceses in the North of Portugal. The present case study attempts to provide an explanation for this, in the light of the theological culture of the Archbishop of Braga, of his position in the Kingdom's political and religious hierarchy and of the few traces of an efficient model to track heresy, in place of the Holy Office: the "pastoral inquisition".
\end{abstract}

Palavras chave/Key words:

Confissão; Inquisição; Justiça episcopal; Teologia; Bartolomeu dos Mártires.

Confession; Inquisition; Episcopal justice; Theology; Bartolomeu dos Mártires 
O frade dominicano Bartolomeu dos Mártires, arcebispo de Braga entre 1559 e 1582, foi beatificado pelo papa João Paulo II, no dia 4 de Novembro de $2001^{1}$. Objecto de escritos hagiográficos, a imagem que dele se procurou transmitir à posteridade sofre, ainda hoje, de profundas distorções em relação ao que foi a sua acção efectiva. É prova disso a substancial continuidade interpretativa entre os seus dois principais biógrafos, ambos dominicanos: o cronista seiscentista D. Frei Luís de Sousa e o historiador contemporâneo Raul de Almeida Rolo². Esta linha confessional não será aqui seguida. O que se pretende é aprofundar o estudo das relações entre a preparação teológica de Bartolomeu dos Mártires e a sua obra como arcebispo, com especial atenção à administração da justiça eclesiástica e à controversa relação que manteve com o Tribunal do Santo Ofício.

\section{Um teólogo num Reino intolerante}

Durante a Idade Moderna, Portugal foi um país rigidamente católico. A religião teve um papel essencial na definição da justificação do poder da Coroa, assim como na construção de um sentimento de identidade comum entre a maioria da população. $\mathrm{O}$ acto fundador desta nova época foi $\mathrm{o}$

1 Indico o ano de 1582 como termo do governo da arquidiocese de Braga por D. frei Bartolomeu dos Mártires, porque o prelado largou a sua posse no dia 23 de Fevereiro desse ano, segundo consta em libelo autógrafo apresentado contra o seu sucessor, D. João Afonso de Meneses, relativo ao vencimento das rendas do arcebispado, ver Arquivo Distrital de Braga (a partir daqui ADB) - Gaveta dos Arcebispos de Braga, doc. 68. Contudo, também é correcto referir o ano antecedente, porque data de 6 de Novembro de 1581 a renúncia de D. frei Bartolomeu e a preconização do seu sucessor, ver PAIVA, José Pedro - Os bispos de Portugal e do Império, 1495-1777. Coimbra: Imprensa da Universidade, 2006, p. 578.

2 SOUSA, Luís de - Vida de D. Frei Bertolameu dos Mártires. Lisboa: INCM Movimento Bartolomeano, 1984 (para uma leitura crítica ver RICARD, Robert - Barthélemy des Martyrs d'apres Luís de Sousa. Essai d'interprétation in RICARD, Robert - Études sur l'histoire morale et religieus du Portugal. Paris: Fundação Calouste Gulbenkian; Centro Cultural Português, 1970); ROLO, Raúl de Almeida - O bispo e a sua missão pastoral segundo D. Frei Bartolomeu dos Mártires. Porto: Movimento Bartolomeano, 1964; ROLO, Raul de Almeida - Formação e vida intelectual de D. Frei Bartolomeu dos Mártires. Porto: Movimento Bartolomeano, 1977; ROLO, Raul de Almeida - Bartolomeu dos Mártires. Obra social e educativa. Porto: Movimento Bartolomeano, 1979. 
baptismo forçado de milhares de judeus presentes no Reino, em $1497^{3}$. A partir daquela data, o alarme contra a ameaça de uma contaminação da pureza da fé dos antigos cristãos por parte dos judeus convertidos, julgados portadores de uma mácula indelével no seu próprio sangue, impôs-se como um dos mais eficazes e duradouros instrumentos de coesão e identificação social.

Durante as primeiras décadas do século XVI, os poderes oficiais tiveram posições diferentes em relação à sinceridade da conversão dos judeus, os quais passaram a ser chamados cristãos-novos. O quadro foi complexo e está ainda insuficientemente conhecido pelos historiadores. Contudo, pode-se afirmar que, enquanto a Coroa seguiu uma linha de oscilação entre limitações e privilégios, a Igreja esteve dividida: entre as várias correntes, sobressaem, de um lado, os bispos contrários à forma violenta dos baptismos e inclinados a negar que aqueles tivessem validade; de outro, os dominicanos intransigentes, prontos a atiçar o fogo da intolerância popular anti-judaica, como foi evidente no episódio do massacre de Lisboa (1506) ${ }^{4}$. Nesse contexto, os cristãos-novos obtiveram a garantia régia de não virem a ser inquiridos por delitos de fé e - segundo a tese de Y.H. Yerushalmi - muitos deles conseguiram preservar a antiga religião judaica, apesar de viverem publicamente como católicos ${ }^{5}$. A distância entre a imagem oficial de um Reino monoconfessional e a realidade da permanência de uma pluralidade religiosa e da separação social entre a maioria cristã e a minoria de origem judaica convertida, acabou por ser o alvo principal do Tribunal do Santo Ofício, criado em $1536^{6}$. A sua fundação foi o resultado das pressões conjuntas da Inquisição espanhola, que pretendia o castigo para

3 SOYER, François - The Persecution of the Jews and Muslims of Portugal. King Manuel and the End of Religious Tolerance (1496-7). Leiden; Boston: Brill, 2007.

4 MARCOCCI, Giuseppe - “... per capillos adductos ad pillam”. Il dibattito cinquecentesco sulla validità del battesimo forzato degli ebrei in Portogallo (1496-1497) in PROSPERI, Adriano (ed.) - Salvezza delle anime, disciplina dei corpi. Un seminario sulla storia del battesimo. Pisa: Edizioni della Normale, 2006, p. 362-381.

5 Esta ideia, já formulada por C. Roth e I.-S. Révah, é apresentada de forma mais sistemática em YERUSHALMI, Yosef Hayim - From Spanish Court to Italian Ghetto. Isaac Cardoso: A Study in Seventeent-Century Marranism and Jewish Apologetics. Seattle; London: University of Washington Press, 1981, p. 3-8.

6 TAVARES, Maria José Ferro - Judaísmo e Inquisição. Estudos. Lisboa: Editorial Presença, 1987. 
os judaizantes castelhanos que residiam em Portugal, de um novo grupo de conselheiros religiosos intransigentes de que o rei D. João III começou a rodear-se, entre o final das décadas de 20 e 30, tal como das necessidades económicas do império colonial português, que se esperava pudessem ser em parte saldadas através do confisco dos bens dos condenados ${ }^{7}$.

O Santo Ofício lusitano teve que vencer muitos obstáculos no início da sua existência. De qualquer maneira, desde 1540 começou a ter lugar nas praças das principais cidades do Reino (onde havia tribunais distritais) o rito dos autos-da-fé, o qual costumava terminar com a execução na fogueira de hereges condenados à morte. Aquela cerimónia, durante dois séculos, tornou-se um espectáculo terrificante, capaz de exprimir uma das facetas fundamentais do catolicismo português na Idade Moderna ${ }^{8}$. Era a religião intolerante de uma sociedade que tinha entre os seus valores dominantes a catequização pelo medo, a segregação das minorias (apesar de convertidas), a censura intelectual. A sua afirmação foi acompanhada pela progressiva redução da autonomia dos outros poderes eclesiásticos que tinham jurisdição sobre a heresia, nomeadamente os bispos e as ordens religiosas ${ }^{9}$. Foi nesse clima de dureza crescente que emergiu a figura de Bartolomeu dos Mártires (1514-90). De origem social humilde, formou-se no Mosteiro de São Domingos de Lisboa, a sua cidade natal, onde professou e acabou os estudos de teologia. O jovem frade cruzou as evoluções do cenário ibérico da sua Ordem. Aderiu às posições dos dominicanos reformadores, inspirados por frei Juan de Hurtado, cujos ideais foram difundidos em Portugal nos finais dos anos 30 por um grupo de frades castelhanos liderados por Jerónimo Padilla. Nessa altura, o ainda jovem, mas já brilhante teólogo começou a

7 MARCOCCI, Giuseppe - La coscienza di un impero. Politica, teologia e diritto nel Portogallo del Cinquecento. Pisa: Scuola Normale Superiore, 2008 (Tese de doutoramento, policopiada), p. 71-74.

8 BETHENCOURT, Francisco - História das Inquisições. Portugal, Espanha e Itália. Lisboa: Círculo de Leitores, 1994, p. 195-257.

9 MARCOCCI, Giuseppe - "Catequização pelo medo"? Inquisitori, vescovi e confessori di fronte ai nuovi cristiani nel Portogallo del Cinquecento in Le inquisizioni cristiane e gli Ebrei. Roma: Atti dei Convegni Lincei, 2003, p. 123-193; MARCOCCI, Giuseppe - custodi dell'ortodossia. Inquisizione e Chiesa nel Portogallo del Cinquecento. Roma: Edizioni di Storia e Letteratura, 2004, p. 45-48; 74-77; 97-99. 
leccionar no Mosteiro da Batalha, o principal studium dominicano existente em Portugal.

Em 1542, com menos de trinta anos, obteve a cátedra de teologia. Explicava as Sentenças de Pedro Lombardo e a Summa Theologiae de Tomás de Aquino aos mais promissores jovens da sua Ordem, dividida então entre facções opostas, e com alguns dos seus mais prestigiados membros a oferecerem o seu serviço ao Santo Ofício ${ }^{10}$. Leitor atento dos principais teólogos da sua época, em 1548 Bartolomeu dos Mártires principiou os comentários à secção mais delicada da Summa de Tomás, a Secunda Secundae, onde se encontram as páginas que o doutor angélico dedicou à heresia e às maneiras de a combater. Nas suas aulas, o frade dominicano encontrou o espaço para expor uma visão alternativa, em comparação com a defendida então pelos inquisidores e pelas personalidades mais severas e intolerantes da Igreja portuguesa (tal como o cardeal infante D. Henrique, inquisidor geral; D. João de Melo e Castro, bispo do Algarve e inquisidor de Lisboa; ou o frade dominicano Jerónimo de Azambuja, censor e deputado do Santo Ofício). A sobrevivência dos cadernos dos apontamentos de frei Bartolomeu consente uma aproximação muito detalhada ao conteúdo das suas palavras e ao seu pensamento neste domínio ${ }^{11}$.

Era ao perigo luterano que ele se referia quando proclamava que contra os hereges manifestos e conscientes, "malfeitores danosos à república", "não se deve disputar, mas actuar com a fogueira"12. Apesar de o luteranismo ter afectado Portugal numa pequena escala (de qualquer maneira, mais do que a historiografia tem tradicionalmente admitido), o medo da infiltração protestante tocou os que circundavam Bartolomeu dos Mártires, e este reconhecia àquela heresia a potencialidade de subverter a ordem da sociedade cristã. Por isso, considerava ser necessário castigar sem demora os culpados, com penas duras, públicas e infamantes. O dominicano, porém, preocupava-

${ }^{10}$ PAIVA, José Pedro - Os Dominicanos e a Inquisição em Portugal (1536-1614) in BERNAL PALACIOS, Artur (ed.), Los Dominicos y la Inquisición en el mundo ibérico e ispanoamericano. Roma: Istituto Storico Domenicano, 2006, p. 505-573.

${ }^{11}$ Os manuscritos teológicos foram descobertos e publicados por R. de Almeida Rolo, cuja edição seguirei, MÁRTIRES, Bartolomeu dos - Theologica Scripta, 6 vols. Braga: Movimento Bartolomeano, 1973-77. As traduções do latim são da minha autoria.

${ }^{12}$ MÁRTIRES, Bartolomeu dos - Theologica Scripta..., cit., vol. 3, p. 90 (q.11); 66 (q. 10). 
-se em distinguir. Nem todos os hereges eram iguais. $\mathrm{O}$ cristianismo era, no seu entendimento, uma religião de amor e caridade. Portanto, conforme a uma tradição acolhida por teólogos e canonistas, ao irmão que errava era preciso oferecer a oportunidade de se arrepender e de voltar à verdade.

Era no rosto misericordioso da Igreja que frei Bartolomeu pensava. E não se tratava de uma fórmula retórica, como acabava por parecer a misericórdia que os inquisidores prometiam aos imputados durante os processos. De facto, no caso do Santo Ofício, a oferta estava condicionada à admissão das culpas. Quando a acusação de heresia chegava ao foro externo do Tribunal era quase impossível tentar uma defesa, e cessava a esperança de evitar a saída pública e ignominiosa em auto-da-fé. Assim, confessar e receber misericórdia significava somente atenuar o rigor da justiça. Mas na tradição da Igreja existiam também outras vias. Num passo do Evangelho de Mateus $(18,15)$ encontrava-se a origem de uma prática muito observada, sobretudo pelas ordens religiosas. De acordo com ela, quem soubesse de uma pessoa que andava enganada em matéria de fé, devia primeiro tentar redimi-la em segredo. Se não tivesse êxito, devia repetir a operação perante duas ou três pessoas. Somente se esta segunda tentativa também falhasse, se tornava inevitável denunciar publicamente o irmão que errava. O sistema da correcção fraterna era radicalmente oposto ao modo de proceder da Inquisição. Ou, pelo menos, assim foi entendido durante o século XVI, quando na Península Ibérica a sua aplicação aos hereges foi longamente debatida ${ }^{13}$.

O problema era o do segredo, da protecção da fama, que constituía um valor fundamental nas sociedades católicas modernas, segundo explicou Vincenzo Lavenia ${ }^{14}$. A intervenção da Inquisição acabava muitas vezes por ser devastante, quebrando os equilíbrios e os compromissos tácitos em que assentava a estabilidade das comunidades. Nos éditos da fé, lidos periodicamente ao povo, os inquisidores mandavam, sem nenhum escrúpulo, que "todos os que souberem algumas cousas contra alguma ou algumas pessoas, de quallquer estado e quallidade sejao, que tenham feito ou

${ }^{13}$ PASTORE, Stefania - A proposito di Matteo 18, 15. 'Correctio fraterna' e Inquisizione nella Spagna del Cinquecento. Rivista Storica Italiana. 113 (2001) 323-368.

${ }^{14}$ LAVENIA, Vincenzo - L'infamia e il perdono. Tributi, pene e confessione nella teologia morale della prima età moderna. Bologna: il Mulino, 2004. 
dito contra a nosa santa fé católica e Santo Oficio da Inquisiçam, o venhão notificar e denumciar ao inquisidor". Nesse esquema não somente desaparecia a discrição garantida pela correcção fraterna, mas também a substância do sigilo da confissão sacramental, que no Regimento do Santo Ofício de 1552 já estava sujeita às exigências judiciárias do Tribunal. De facto, encomendava-se aos delatores que "o que assi souberem tocando à Santa Inquisiçam, nam o diguam, nem descubram a alguma pessoa, de quallquer qualidade que seja, salvo a seus confessores, sendo taes pessoas que lhes possam bem aconselhar o que sam niso obriguados a fazer, e os confessores lhe mandaram que o venham loguo denunciar aos inquisidores" ${ }^{15}$. Assim, o sistema da recusa da absolvição aos fiéis foi aumentando a vigilância do Santo Ofício sobre os confessores, chegando a favorecer, no limite, casos de aberta violação do sigilo por parte de sacerdotes demasiado zelosos ${ }^{16}$.

Ao contrário, nas suas lições, Bartolomeu dos Mártires defendeu vigorosamente o carácter inviolável do sacramento da penitência. O dominicano respeitava a interpretação comum dos doutores da Igreja, segundo a qual o percurso protegido da correcção fraterna estava reservado aos hereges ocultos. Assim se criava uma conexão directa entre os pecados apreendidos pelo confessor e a prática da correcção de um herege: um herege oculto, como esclarecia frei Bartolomeu, recuperando uma distinção própria do direito canónico. Contudo, as esferas da heresia pública, também dita manifesta, e da secreta, igualmente designada oculta, tendiam a confundir-se, não sendo claramente delimitadas. Um adágio corrente sustentava: "a Igreja não julga as culpas ocultas", o que significava que nos tribunais eclesiásticos não se podiam processar os fiéis por culpas não públicas ${ }^{17}$. Mas quando é que uma culpa era pública? A resposta não era unívoca. Bartolomeu dos

${ }^{15}$ As duas citações são tiradas do Regimento do Santo Oficio in BAIÃO, António A Inquisição em Portugal e no Brasil. Subsidios para a sua História. Lisboa: Edição do Arquivo Histórico Português, 1920, doc. 31 (cap. 4). Sobre a ligação entre a Inquisição e o sacramento da confissão ver PROSPERI, Adriano - Tribunali della coscienza. Inquisitori, confessori, missionari. Torino: Einaudi, 1996, p. 19-257. Para o caso português ver MARCOCCI, Giuseppe - I custodi..., cit., p. 237-335.

${ }^{16}$ Exemplos concretos são apresentados em MARCOCCI, Giuseppe - I custodi..., cit., p. 256-266.

${ }^{17}$ CHIFFOLEAU, Jacques - "Ecclesia de occultis non iudicat"? L'Eglise, le secret, l'occulte du XIIe au XVe siècle. Micrologus. 14 (2006) 359-481. 
Mártires tinha uma opinião firme, que se situava na linha do afamado teólogo dominicano quinhentista Tommaso de Vio, o cardeal Caietano. Não era suficiente que a culpa tivesse sido cometida perante outras pessoas, ou que fosse conhecida por alguém. Era necessário que o pecador fosse "infamado na comunidade" ${ }^{18}$. A distância desta doutrina em relação ao modelo do Santo Ofício era evidente.

A interpretação social da culpa, defendida por frei Bartolomeu, tinha como consequência uma maior sensibilidade para a consciência individual. O prelado honesto devia zelar pela preservação de uma esfera protegida, onde a correcção fraterna pudesse actuar para recuperar a alma do pecador, mesmo que se tratasse de um herege. Aqui adquiria significado especial a distinção proposta pelo teólogo dominicano entre um tipo de prelado "espiritual, pio, discreto, cuidadoso com a consciência e a fama do próximo" e o padrão oposto, "rancoroso, pronto para tornar públicos e punir os pecados ocultos dos seus súbditos". Nesta categoria, que correspondia ao ideal de bispo pretendido quer pelos inquisidores, quer pelas figuras mais intransigentes na hierarquia do Reino, entravam "os juízes das culpas ocultas". De forma explícita, Bartolomeu dos Mártires sublinhava que "erram aqueles prelados que logo difamam e castigam os pecados deste género"19. Contudo, dado o clima vigente em Portugal, não deixou de ponderar com cuidado os casos em que um herege oculto devia gozar da correcção fraterna. "Se for tal", ensinava o dominicano, "de que esteja certo que só prejudica a si mesmo, e não haja medo que engane ou favoreça outros hereges, então não deve ser denunciado antes da admoestação secreta, se houver esperança de o emendar". Se a tentativa tivesse sucesso, eram desnecessárias posteriores providências ${ }^{20}$. Esta solução tendia a evitar o julgamento público num tribunal. Ou melhor, permitia que um caso de heresia não grave fosse resolvido no foro interior, isto é, no momento reservado do sacramento da confissão, ou perante um delegado do bispo - por norma, o penitenciário

\footnotetext{
${ }^{18}$ MÁRTIRES, Bartolomeu dos - Theologica Scripta..., cit., vol. 3, p. 287 (q. 33).

${ }^{19}$ Ibid., p. 281; 291; 299 (q. 33).

${ }^{20}$ Ibid., p. 293 (q. 33).
} 
da Sé - que tivesse faculdade de absolver o delito de heresia no foro da consciência, segundo a expressão usada por canonistas e teólogos ${ }^{21}$.

O problema principal em Portugal era representado pelos cristãos-novos suspeitos de criptojudaísmo, muitas vezes por causa de pequenos detalhes que um processo da Inquisição era capaz de transformar em provas irrefutáveis. É natural que Bartolomeu dos Mártires pensasse neles quando definia como sendo "oculto" até um pecado cometido conjuntamente por dez pessoas, como era usual no caso das práticas judaicas, que na maioria se reportavam a ritos e costumes antigos observados no seio da família ${ }^{22}$. A densidade da noção de pecado público como acto pelo qual o responsável estava infamado na comunidade inteira ressalta com toda evidência. Mas a crítica indirecta de frei Bartolomeu contra os métodos do Santo Ofício chegava até ao ponto de sustentar que se um convertido não tinha ainda uma fé tão firme que soubesse distinguir a verdade dos erros, então não podia ser culpado, em razão da sua "ignorância invencível"23. Tratava-se de um princípio tomista, que tendo sido aceite em relação aos cristãos-novos, teria minado a base de intervenção da Inquisição.

\section{Do claustro à vida activa}

Em 1551 Bartolomeu dos Mártires obteve o prestigiado título de mestre em teologia pela congregação geral dos dominicanos, reunida em Salamanca. No ano seguinte trocou a Batalha por Évora, onde se tornou preceptor de D. António, o futuro prior do Crato. Numa cidade que era um dos maiores

${ }^{21}$ Sobre a longa história do sistema de absolvição secreta da heresia ver BRAMBILLA, Elena - Alle origini del Sant'Uffizio. Penitenza, confessione e giustizia dal medioevo al XVI secolo. Bologna: il Mulino, 2000.

${ }^{22}$ MÁRTIRES, Bartolomeu dos - Theologica Scripta..., cit., vol. 3, p. 304 (q. 33).

${ }^{23}$ Ibid., p. 268 (q. 33). Naquela altura, a noção era aplicada também aos convertidos do Novo Mundo, ver PAGDEN, Anthony - The fall of natural man. The American Indian and the origins of comparative ethnology. Cambridge: Cambridge University Press, 1982, p. 67. Bartolomeu dos Mártires parece manter de propósito alguma ambiguidade entre nível europeu e nível colonial, seguindo uma linha que ia em sinal contrário à estratégia observada no Império pelas autoridades portuguesas, ver XAVIER, Ângela Barreto - De converso a novamente convertido. Identidade política e alteridade no Reino e no Império. Cultura. Revista de Teoria e História das Ideias. 22 (2006) 245-275. 
focos da espiritualidade mística da Península Ibérica, teve a oportunidade de contactar não somente com a principal figura da hierarquia eclesiástica portuguesa, o cardeal infante D. Henrique, arcebispo local e inquisidor geral, mas sobretudo com um novo instituto religioso, a Companhia de Jesus, e com o dominicano castelhano frei Luis de Granada, o homem que tinha facilitado a chegada dos discípulos de Inácio de Loyola à cidade alentejana ${ }^{24}$.

Até então homem de vida contemplativa, em Évora, frei Bartolomeu pôde assistir ao exemplo contagioso de uma espiritualidade que parecia tornarse acção pastoral, através das missões no interior, da palavra dos sermões, da experiência cada vez mais difundida do diálogo com a consciência individual no espaço íntimo da confissão ${ }^{25}$. Na obra dos jesuítas que, com licença do arcebispo D. Henrique, reconciliavam os litigantes nas aldeias, ensinavam os rudimentos da fé aos meninos e aos simples, administravam os sacramentos, assim como no percurso de meditação interior em que teve como guia espiritual Granada, Bartolomeu dos Mártires encontrou uma aplicação concreta do ideal de prelado que tinha esboçado nas suas aulas de teologia. Na primeira metade dos anos 50 foi eleito prior do Convento de Benfica e teve a primeira experiência na administração de uma instituição eclesiástica. Contudo, a sua fama estava ligada sobretudo à ampla cultura teológica e à frequentação dos círculos espirituais de Lisboa, onde abundavam os grandes vultos da cena política, quando, em 1558, foi nomeado arcebispo de Braga, em substituição do defunto carmelita D. frei Baltasar Limpo. Foi assim que um humilde dominicano de origens obscuras foi criado, por vontade da regente D. Catarina, titular da mais ilustre Sé de Portuga ${ }^{26}$. Nos anos seguintes, frei Bartolomeu iria confirmar

${ }^{24}$ BATAILLON, Marcel - L'implantation de la Compagnie de Jésus au Portugal in BATAILLON, Marcel - Études sur le Portugal au Temps de l'Humanisme. Paris: Fundação Calouste Gulbenkian; Centro Cultural Português, 1975, p. 221-224.

${ }^{25}$ O'MALLEY, John - The First Jesuits. Cambridge (Mass.): Harvard University Press, 1994, p. 91-157; para o caso português ver PALOMO, Federico - Fazer dos campos escolas excelentes. Os jesuitas de Évora e as missões do interior em Portugal (1551-1630). Lisboa: Fundação Calouste Gulbenkian; Fundação para a Ciência e a Tecnologia, 2003.

${ }^{26}$ PAIVA, José Pedro - Os bispos ..., cit., p. 331-332, interpreta a escolha de Bartolomeu dos Mártires como uma solução de compromisso, numa conjuntura política instável. 
a sua fidelidade à rainha, da qual foi um precioso conselheiro nos anos atormentados da regência na menoridade de $\mathrm{D}$. Sebastião $0^{27}$.

Bartolomeu dos Mártires tomou posse da arquidiocese em 1559. Tratava-se da maior do Reino, com um território vasto e irregular, que abrangia o Entre-Douro-e-Minho e uma grande parte do Trás-os-Montes, contando mais de mil e duzentos freguesias. Além disso, o arcebispo de Braga era também senhor temporal da cidade e dos seus $\operatorname{coutos}^{28}$. D. frei Bartolomeu procurou sempre proteger a especial autonomia jurisdicional de que tradicionalmente gozava o cargo que ele exercia. De facto, a estratificação de antigos privilégios e direitos tornava muito complexa a rede de poderes em Braga e nos seus arredores, mas o novo arcebispo conseguiu consolidar e aumentar a sua própria autoridade ${ }^{29}$. Logo em Setembro de 1559 a Rainha concedeu-lhe novas faculdades de visitação ${ }^{30}$. E numa evidente estratégia de centralização, Bartolomeu dos Mártires actuou para eliminar qualquer resistência por parte do Cabido da Sé, o qual, como no resto da Europa católica, era o maior rival à afirmação da autoridade episcopal. O dominicano era um prelado enérgico. Contudo, em primeiro lugar, era um pastor, isto é um religioso que aspirava a uma radical reforma da sociedade, a partir de um primado autêntico dos valores cristãos. As visitas, o catecismo e a pregação foram as suas principais armas. Os documentos parecem confirmar a imagem de um arcebispo zeloso, que tomou sobre si a tarefa de transformar uma área de profunda ignorância a respeito da doutrina e da moral católica, numa terra onde cada ovelha podia ser conduzida pelo seu pastor ao longo de um caminho seguro até a salvação ${ }^{31}$. Desde 1560, D. frei Bartolomeu

${ }^{27}$ CRUZ, Maria do Rosário de Sampaio Themudo Barata de Azevedo - As regências na menoridade de D. Sebastião. Elementos para uma história estrutural. Lisboa: INCM, 1992, vol. 1, p. 204.

${ }^{28}$ MARQUES, José - Senhorio de Braga e Arcebispos da Independência. Bracara Augusta. 49 (2000) 127-174.

${ }^{29}$ SILVA, Francisco Ribeiro da - Senhorio e municipalismo em Braga ao tempo de D. Frei Bartolomeu dos Mártires in IX Centenário da Dedicação da Sé de Braga. Actas do congresso internacional. Braga: UCP; Cabido Metropolitano e Primacial de Braga, 1990, vol. 2/2, p. 7-27.

${ }^{30}$ SOARES, António Franquelim Sampaio Neiva - A arquidiocese de Braga no século XVI: visitas pastorais e livros de visitações. Porto: Universidade do Porto, 1972, p. 124-125 (tese de licenciatura policopiada).

${ }^{31}$ Para as fontes sobre a vida de Bartolomeu dos Mártires ver ROLO, Raúl de Almeida - Itinerário documental de uma vida. Bracara Augusta. 42 (1990) 525-726. 
empenhou-se em percorrer incessantemente as localidades da arquidiocese, escolhendo auxiliares de confiança absoluta, como o confrade João de Leiria, nomeado vigário geral, e os padres da Companhia de Jesus, que logo naquele ano abriram um colégio em Braga $^{32}$.

A presença do novo arcebispo foi sentida como uma profunda mudança pelos habitantes da cidade. O predecessor, D. frei Baltasar Limpo, um prelado intransigente, cuja antiga ligação à Inquisição tinha favorecido a sua promoção à dignidade episcopal, tinha governado com dureza. $\mathrm{Na}$ Braga onde ingressou Bartolomeu dos Mártires estava ainda aberta a ferida das capturas e dos numerosos processos (vinte e três) celebrados pelo Santo Ofício, em Lisboa, contra membros da relevante comunidade urbana de cristãos-novos. O carmelita Limpo estava na origem daquelas prisões, que remontavam ao ano de $1558^{33}$. Foi exactamente para o despacho daquelas causas que, logo depois da sua entrada, o novo arcebispo dominicano delegou o seu voto de ordinário, colaborando com os inquisidores de Lisboa $^{34}$. A repercussão das condenações decorrentes destes processos manteve dividida a cidade durante anos ${ }^{35}$. No entanto, neste quadro, D. frei Bartolomeu não se resignou a ser o senhor poderoso de uma sociedade em conflito. O seu foi um projecto de reconciliação dentro de um modelo de vigilância rigoroso. Os instrumentos mais eficazes de que se serviu para realizar o seu modelo de governo pastoral foram o conhecimento directo da realidade que administrava, a inspecção de faltas e erros dos fiéis mediante as visitas, a procura de uma sincera conversão à fé através da catequese, da pregação e do arrependimento, este gerido no segredo da confissão, um

${ }^{32}$ Sobre as primeiras visitas ver SOARES, António Franquelim Sampaio Neiva Visitações e Itinerários Pastorais de D. Fr. Bartolomeu dos Mártires. Bracara Augusta. 42 (1990), 171-213, especialmente p. 186-195. Acerca da chegada dos jesuítas ver RODRIGUES, Manuel Augusto - D. frei Bartolomeu dos Mártires e o Colégio de S. Paulo de Braga. Lusitania Sacra. 10 (1978) 101-133.

${ }^{33}$ MEA, Elvira Cunha de Azevedo - O procedimento inquisitorial garante da depuração das visitas pastorais de Braga (Século XVI) in IX Centenário..., cit., vol. 2/2, p. 67-95, em especial p. 70-71.

${ }^{34}$ Carta de 19 de Setembro de 1559, publicada em PEREIRA, Isaías da Rosa - Documentos para a história da Inquisição em Portugal (Século XVI). Lisboa: Cáritas Portuguesa, 1987, p. 81 .

${ }^{35}$ SOARES, António Franquelim Sampaio Neiva - A freguesia de Sant'Iago da Sé na visitação capitular de 1562: a mulher que matava crianças. Bracara Augusta. 40 (1989-90) 205-263, sobretudo p. 223-224. 
lugar privilegiado para resolver tanto as crises pessoais, como os contrastes sociais quotidianos.

Governo pastoral, "poder pastoral”. Estamos próximos do núcleo da personalidade eclesiástica e política de um homem que regeu a mais titulada e extensa diocese do Reino durante mais de vinte anos. Bartolomeu dos Mártires foi também um grande impulsionador de reformas institucionais e de estruturas educativas e judiciais. Não há dúvida que geriu um extraordinário poder. Mas qual era a natureza deste poder? Havia alguma diferença em comparação com a outra figura cimeira da Igreja portuguesa da altura, o cardeal infante D. Henrique, cuja autoridade estava ligada sobretudo à temida ameaça da Inquisição, um Tribunal alicerçado na infâmia e na publicidade de castigos violentos?

Um possível indício é fornecido por um ilustre e próximo biógrafo de ambos. Da figura de D. Henrique, frei Luis de Granada iria distinguir entre o "pastor", por um lado, e o "inquisidor" por outro; pelo contrário, no caso de D. frei Bartolomeu, seria possível manter uma representação unitária da sua acção, sob a etiqueta de um "solícito e vigilante pastor" ${ }^{36}$. Apesar de este último ser um prelado determinado, também ele pronto a usar penas exemplares contra clérigos e leigos prevaricadores, era grande a distância entre as vias propostas por um inquisidor como o cardeal infante, que fundava a sua estratégia no medo da fogueira, e os caminhos de um arcebispo que, no máximo, chegou a impor penitências (às vezes severas) em praças da cidade ou dentro de uma igreja.

O sistema de poder criado por Bartolomeu dos Mártires na arquidiocese de Braga aproxima-se de uma dimensão específica, sobre a qual chamou a atenção Michel Foucault. O ponto de partida é a recusa da ideia segundo a qual "as relações de poder se limitam a constranger e forçar". A intuição de Foucault partia da análise da sociedade contemporânea, na qual ele via permanências de uma técnica de poder cujos efeitos se notariam sobretudo a um nível difuso. Um "poder”, explicava, "que no Ocidente existe desde

${ }^{36}$ GRANADA, Luis de - História de las virtudes y oficio pastoral del Serenísimo Cardenal don Henrique, Arzobispo de Évora, que despues fué gloriosísimo Rey de Portugal in GRANADA, Luis de - Obras Completas, (ed. por A. Huerga). Madrid: Fundación Universitaria Española; Dominicos de Andalucía, 1997, vol. 16, p. 135; GRANADA, Luis de - Vida de don fray Bartolomé de los Mártires, Arzobispo de Braga, ibid., p. 165. 
a Idade Média, uma forma de poder que não é político, nem jurídico, nem sequer económico, ou de dominação étnica, mas que, contudo, estruturou em profundidade as nossas sociedades. Este poder tem uma origem religiosa, pretende guiar e dirigir os homens durante a vida inteira e em qualquer circunstância, quer tomar a seu cargo a existência de cada homem do nascimento até à morte, para o constranger a se comportar numa certa maneira, para obter a salvação. É aquilo que poderíamos chamar poder pastoral". Isto é, literalmente, "o poder que o pastor exerce sobre a grei". Foucault articulava este poder directamente com a Igreja e a ordem da sociedade cristã, sublinhando como este processo tivesse tido no século XVI, "com a Reforma e a Contra-Reforma", um pico de intensidade. A noção de "poder pastoral" mostra correspondências significativas com a estratégia de administração eclesiástica seguida por D. frei Bartolomeu, um símbolo europeu da Contra-Reforma: "preocupa-se e cuida essencialmente com vigiar sobre a salvação de todos", prosseguia Foucault, "tomando a seu cargo cada aspecto particular, cada ovelha da grei: além de constranger o indivíduo a actuar de uma certa maneira, tenta conhecê-lo, descobri-lo, perceber a sua subjectividade e organizar a relação que este tem consigo e com a sua consciência". Assim, na construção daquele poder teve um papel decisivo o sacramento da confissão. Existia uma profunda relação entre a verdade interior e o poder pastoral, "que o torna um poder individualizador"37.

Sem nenhuma pretensão de coincidência entre os modelos teóricos e a complexidade dos processos históricos, nas próximas páginas tentarei reflectir, com base no esquema de Foucault, acerca dos poucos dados concretos relativos ao controlo da ortodoxia que as fontes conservam do período de Bartolomeu dos Mártires. Este foi uma figura cuja modernidade vincada na tradição parece tornar o seu caso comparável com os coevos de Pedro Guerrero, arcebispo de Granada, e do cardeal Carlo Borromeo,

${ }^{37}$ O texto de referência sobre o "poder pastoral” é M. FOUCAULT - Sécurité, territoire, population. Cours au Collège de France, 1977-1978, éd. par M. Senellart sous la dir. de F. Ewald - A. Fontana. Paris: Gallimard; Seuil, 2004. Ver também M. FOUCAULT La philosophie analytique de la politique [1978] in M. FOUCAULT - Dits et écrits, 1954-1988, éd. sous la dir. de D. Defert - F. Ewald. Paris: Gallimard, 1994, vol. 3, p. 534-551 (donde são tiradas as citações). Uma reflexão recente em PH. BÜTTGEN - Théologie politique et pouvoir pastoral. Annales. Histoire, Sciences sociales. 62 (2007) 1129-1154. 
arcebispo de Milão ${ }^{38}$. As relações estreitas que o prelado português manteve com ambos, durante a primeira metade dos anos 60, representam uma via privilegiada para penetrar no complexo universo da "inquisição pastoral" de D. frei Bartolomeu ${ }^{39}$.

\section{Uma outra inquisição}

Durante os vinte e três anos em que Bartolomeu dos Mártires administrou a arquidiocese de Braga, os seus súbditos que chegaram a ser processados pelo Santo Ofício foram muito poucos. Pouquíssimos, se confrontados com os fiéis de outras dioceses que foram julgados, na mesma altura, pela Inquisição (desde 1565 o Tribunal de Coimbra passou a ter competência sobre o território governado pelo arcebispo dominicano $)^{40}$. Os números por si só não resolvem a compreensão do problema ${ }^{41}$. A perda quase integral dos fundos judiciais do arquivo do Auditório Eclesiástico de Braga impede que se conheça cabalmente o que aconteceu então na arquidiocese. Contudo, é possível levantar questões relevantes acerca do modelo de vigilância sobre

${ }^{38}$ PASTORE, Stefania - Il Vangelo e la spada. L'Inquisizione di Castiglia e i suoi critici (1460-1598). Roma: Edizioni di Storia e Letteratura, 2003, p. 369-383; A. BORROMEO - L'arcivescovo Carlo Borromeo e la lotta contro l'eresia in F. BUZZI-D. ZARDIN (eds.) - Carlo Borromeo e l'opera della "grande riforma". Cultura, religione e arti del governo nella Milano del pieno Cinquecento. Milano: Silvana, 1997, p. 303-322.

39 A expressão "Inquisição "pastoral"” encontra-se já em PROSPERI - Tribunali..., cit., p. 412-417, para significar os métodos moderados e pedagógicos em relação à perseguição da magia popular e superstição, adoptados pelo Santo Ofício romano, a partir do século XVII.

${ }^{40}$ Ver os valores propostos por MEA, Elvira Cunha de Azevedo (ed.) - Sentenças da Inquisição de Coimbra em metropolitanos de D. Frei Bartolomeu dos Mártires (1567-1582). Porto: Arquivo Histórico Dominicano Português; Movimento Bartolomeano, 1982, p. LXVII-LXIX (os habitantes da arquidiocese de Braga processados foram apenas 52, num total de cerca de 600 processos instaurados por este Tribunal distrital; como elemento de comparação considere-se que, na mesma altura, os da diocese de Coimbra foram 226, de Lamego 180, de Viseu 85).

${ }^{41}$ Chama a atenção para os limites da historiografia sobre os dados quantitivos do Santo Ofício português DEL COL, Andrea - L'Inquisizione in Italia dal XII al XXI secolo. Milano: Mondadori, 2006, p. 255. 
a ortodoxia vigente na região, no tempo de D. frei Bartolomeu ${ }^{42}$. Durante o seu arcebispado houve, na maior parte do Norte de Portugal, um sistema de justiça religiosa alternativo à Inquisição? Seja qual for a resposta, perguntase qual foi a relação entre a peculiar dimensão jurisdicional do território bracarense e as autoridades politicas e eclesiásticas do Reino?

Apesar de limitar a análise à matéria da heresia, quero deixar claro que o projecto global de reforma da sociedade empreendido pelo arcebispo de Braga foi, em simultâneo, alimentado por iniciativas no campo da formação do clero, da catequização do povo, dos estímulos a novos cultos e devoções. No contexto do Portugal da Contra-Reforma, foi um dos exemplos mais avançados de aplicação dos decretos do Concílio de Trento e de reafirmação da autoridade da Igreja ${ }^{43}$. A defesa da fé era a arquitrave do edifício que Bartolomeu dos Mártires tentou construir. Isto ficou manifesto logo nas sessões da terceira fase do Concílio de Trento (1561-63), na qual o dominicano tomou parte activa. Juntamente com o arcebispo Guerrero e outros prelados, na maioria ibéricos, lutou para que fosse reconhecida aos bispos a faculdade de absolver a heresia oculta no foro da consciência ${ }^{44}$. O diário tridentino do arcebispo português comprova que a sua intenção original era até mais ampla. De facto, o que ele pretendia era que os bispos pudessem resolver qualquer delito contra a fé, "desde que o Santo Ofício da Inquisição não procedesse já contra ele" 45 . A noção de heresia oculta, portanto, alargava-se até coincidir com qualquer caso que não tivesse chegado ao foro externo, ou seja, ao conhecimento de um tribunal. No fundo, é na reivindicação deste poder autónomo sobre a esfera da consciência que reside a distância entre

${ }^{42}$ Problema já levantado em MEA, Elvira Cunha de Azevedo - A Inquisição de Coimbra no século XVI. A Instituição, os Homens e a Sociedade. Porto: Fundação Eng ${ }^{\circ}$ António de Almeida, 1997, p. 212.

${ }^{43}$ Uma panorâmica geral desta época em Portugal pode ver-se em PALOMO, Federico A Contra-Reforma em Portugal, 1540-1700. Lisboa: Livros Horizonte, 2006.

${ }^{44}$ PASTORE, Stefania - Roma, il concilio di Trento, la nuova Inquisizione: alcune considerazioni sui rapporti tra vescovi e inquisitori nella Spagna del Cinquecento in Le inquisizioni cristiane..., cit., p. 109-146; MARCOCCI, Giuseppe - Il governo dell'arcidiocesi di Braga al tempo di Bartolomeu dos Mártires (1559-1582). Archivio Italiano per la Storia della Pietà. 15 (2003) 81-150, em especial p. 93-108.

${ }^{45}$ MÁRTIRES, Bartolomeu dos - Collecta in Concilio Tridentino circa decreta discutienda [xeroc. do orig.], in Arquivo Histórico Dominicano Português (Porto), cx. 44, IV, 1, fl. 197. 
a inquisição pastoral de D. frei Bartolomeu e a verdadeira Inquisição de D. Henrique, a qual prosseguia, inexoravelmente, queimando cristãos-novos em número crescente. A dura reacção do embaixador português no Concílio de Trento, D. Fernão Martins Mascarenhas, quando foi aprovado o cânone sustentado por Guerrero e Bartolomeu dos Mártires (o qual não escondeu a sua própria satisfação ao cardeal Borromeo), confirma que, na óptica da Coroa - era então regente o cardeal infante D. Henrique -, aquele resultado foi tomado como uma derrota ${ }^{46}$.

O problema não era abstracto. No quadro da perda quase completa de fontes sobre a actividade judiciária dos tribunais diocesanos em Portugal, e apesar da carência de documentos acerca das relações directas entre bispos e inquisidores, os historiadores concordam em que estas, em geral, foram de estreita colaboração ${ }^{47}$. Contudo, na minha opinião, o equilíbrio entre as duas autoridades eclesiásticas não foi alcançado imediatamente após a criação da Inquisição, sendo antes o resultado de um processo de progressiva expansão da capacidade hegemónica do Santo Ofício nas estruturas da Igreja lusitana. Estudos de caso, como aquele proposto aqui sobre a arquidiocese de Braga, procuram precaver os riscos de uma visão uniformizadora, a qual pode derivar de um uso excessivo das sugestões da historiografia do "disciplinamento social" pretensões dos inquisidores, houve bispos que continuaram a gerir casos de heresia em total autonomia. Foi contra estes prelados que o cardeal infante tinha pedido e obtido o breve Cum audiamus (1561), cujo texto denunciava de forma explícita a existência do fenómeno, concedendo, por consequência,

${ }^{46}$ Carta de Fernão Martins Mascarenhas ao rei D. Sebastião, Trento, 15 de Novembro de 1563, publicada em Corpo Diplomatico Portuguez..., Lisboa: Typographia da Academia Real das Sciencias, 1862-1959, vol. 10, p. 139-140; carta de Bartolomeu dos Mártires ao cardeal Carlo Borromeo, Trento, 15 de Novembro de 1563, publicada em ROLO, Raúl de Almeida - O "Bracarense" padre conciliar in IV Centenário da morte de D. Frei Bartolomeu dos Mártires. Actas do congresso internacional. Fatima, Movimento Bartolomeano, 1994, p. 299.

${ }^{47}$ PAIVA, José Pedro - Os bispos e a Inquisição portuguesa (1536-1613). Lusitania Sacra. $2^{\text {a }}$ série, 15 (2003) 43-76.

${ }^{48}$ Sobre as diferentes perspectivas entre micro-história e disciplinamento social ver a reflexão dedicada ao caso da historiografia italiana por BOER, Wietse de - Social Discipline in Italy: Peregrinations of a Historical Paradigm. Archiv für Reformationsgeschichte, 94 (2003) 294-307. 
ao inquisidor geral a faculdade de avocar a si qualquer processo por crimes contra a fé pendente num auditório eclesiástico e de subdelegar tal faculdade a pessoas de sua confiança ${ }^{49}$. Acerca desta grande concentração de poderes na pessoa de D. Henrique manteve uma atitude crítica, entre outros, também o arcebispo de Braga, o qual, consultado pouco antes pela rainha D. Catarina acerca da passagem da regência a $\mathrm{D}$. Henrique, tinha objectado que havia o perigo de que "não tenhamos nem cardial, nem governador" ${ }^{50}$. Em seguida, o descontentamento dos bispos pela humilhação do breve Cum audiamus deixou rasto também nos apontamentos apresentados pelo estado do clero nas Cortes (1562-63) que proclamaram regente o príncipe inquisidor ${ }^{51}$. Foi neste movimentado contexto que Bartolomeu dos Mártires lutou em Trento para a conservação das faculdades episcopais, voltando a Portugal, em 1564, com a firme intenção de impôr o respeito dos decretos conciliares.

Na pátria as relações de força estavam diferentes. Ao arcebispo de Braga não convinha ser protagonista de uma outra batalha aberta. A falta de um autêntico debate no Reino sobre assuntos delicados, como era a erradicação da heresia, aconselhava cautela. D. frei Bartolomeu evitou um choque frontal com a Inquisição, e até recorreu à sua temida autoridade depois do sínodo diocesano (1564), onde explodiram conflitos com os cónegos da Sé para os aplacar ${ }^{52}$. Foi exactamente para os reduzir à obediência que o prelado dominicano pediu ao Santo Ofício para realizar uma visita na cidade e nos seus arredores ${ }^{53}$. A presença do inquisidor Pedro Alvarez de Paredes, no Porto, Braga e noutras importantes localidades da arquidiocese, entre 1564 e 1565, despertou antigas inimizades, e conduziu algumas testemunhas

${ }^{49}$ Publicado em Corpo Diplomatico Portuguez..., cit., vol. 9, p. 233.

${ }^{50}$ Carta de Bartolomeu dos Mártires à rainha D. Catarina, Braga, 7 de Janeiro de 1561, publicada em ROLO, Raúl de Almeida - Itinerário documental..., cit., p. 559-560.

${ }^{51}$ CRUZ, Maria do Rosário de Sampaio Themudo Barata de Azevedo - As regências..., cit., vol. 1, p. 361-363; MARCOCCI, Giuseppe - I custodi dell'ortodossia ..., cit., p. 165-170 .

${ }^{52}$ ROLO, Raúl de Almeida - L'application de la réforme du Concile de Trente à Braga in Il Concilio di Trento e la riforma tridentina. Atti del convegno storico internazionale. Roma: Herder, 1965, vol. 2, p. 555-576; SOARES, António Franquelim Sampaio Neiva A "tridentinização" da Arquidiocese de Braga. Os Sínodos Bartolomeanos. Theologica. 33 (1998) 433-489, sobremaneira p. 461-489.

${ }^{53}$ Protesto dos cónegos da Sé de Braga apresentado no IV Concílio provincial bracarense (1566), in ADB - Gaveta de Concílios e Sínodos, doc. 15, fl. 8v-9. 
a denunciarem ao visitador as dúvidas que tinham acerca de pecados alheios, os quais era mais usual que se confidenciassem ao confessor. Mas o objectivo principal da devassa de Alvarez de Paredes eram os cónegos ${ }^{54}$. Contra o capitular mais destacado, o cónego cristão-novo João Afonso, a Inquisição abriu um processo, sem emitir qualquer sentença ${ }^{55}$. Pelo contrário, entre as pessoas denunciadas por outras heresias, muito poucas foram processadas. Aliás, o registo das confissões e das acusações do visitador inquisitorial não fornece somente numerosas provas da actividade do sistema de justiça pastoral de Bartolomeu dos Mártires, mas confirma também como, na arquidiocese, a coesão social não se realizava principalmente a partir do medo dos cristãos-novos. Foram escassos os delitos de criptojudaísmo levados ao conhecimento do inquisidor. E entre os processos que o Santo Ofício de Lisboa chegou a celebrar, ressalta o caso de Graça Dias, que nem sequer era cristã-nova, como demonstrou perante os juízes, acabando por ser solta, em Abril de $1566^{56}$.

De facto, nos anos seguintes, a Inquisição não conseguiu entrar realmente no território da arquidiocese, cuja jurisdição, segundo o costume dos prelados bracarenses, foi defendida com determinação também contra representantes do poder régio (ver os casos de Francisco de Lima em 1567 e de Pedro da Cunha em 1570) ${ }^{57}$. Neste espaço de autonomia D. frei Bartolomeu experimentou as suas ideias de reforma: uma reforma centrada, em primeiro lugar, num minucioso sistema de visitadores diocesanos, que inquiriam sobre os delitos de fé, e aos quais foram concedidas as faculdades de absolvição

${ }^{54}$ Ver o Livro da Visitação que se [a Inquisição] fez na Cydade de Braga e seu Arcebispado [1565] (ed. por A. do Rosário). Porto: Arquivo Histórico Dominicano Português; Movimento Bartolomeano, 1974. O objectivo desta visita escapou a BRAGA, Isabel M.R.M. Drumond - A visita da Inquisição a Braga, Viana do Castelo e Vila do Conde em 1565. Revista de la Inquisición. 3 (1994) 29-67.

${ }_{55}$ Arquivo Nacional da Torre do Tombo (Lisboa) (a partir daqui ANTT) - Inquisição de Coimbra, proc. 9774.

${ }_{56}$ ANTT - Inquisição de Lisboa, proc. 5794.

${ }^{57}$ MACHADO, Diogo Barbosa-Memorias para a História de Portugal, que comprehendem o governo delRey D. Sebastião .... Lisboa: José António da Silva, 1736-51, vol. 2, p. 638-639 (ao delegado régio Lima foi impedido aprovar e assinar as actas finais do Concílio provincial bracarense); FERREIRA, José Augusto - Fastos Episcopais da Igreja Primacial de Braga (Sec. III - Sec. XX). Braga: Mitra Bracarense, 1928-34, vol. 3, p. 48-52 (ao juiz Cunha, que estava a conduzir uma visitação judicial régia, foi vedado o ingresso nos territórios sob a jurisdição de Bartolomeu dos Mártires). 
previstas pelo Concílio de Trento ${ }^{58}$. Ao lado deles, em contacto com a rede dos vigários, actuavam os missionários jesuítas (eles também providos de poderes especiais na remissão da heresia $)^{59}$. Os padres andavam pelas inúmeras aldeias da arquidiocese, na tentativa de catequizar camponeses, montanheses e outros rústicos. Foi para a instrução religiosa deles que Bartolomeu dos Mártires publicou o seu Catecismo ou Doutrina Cristã e Práticas Espirituaes (1564), cujas edições se repetiram durante anos.

O pecado, o erro, até a heresia - a não ser clamorosa -, deviam primeiro encontrar o rosto misericordioso da Igreja, os agentes da correcção fraterna, a possibilidade de se redimir sem consequências no plano exterior. O poder pastoral do arcebispo exercia-se no interior das consciências. Foi para reforçar este modelo de "conquista da alma" - para retomar o título de um livro de Wietse De Boer sobre a Milão de Carlo Borromeo - que um lugar central no sistema de justiça elaborado por Bartolomeu dos Mártires foi conferido ao penitenciário mor, figura delegada para resolver os casos reservados, incluindo a heresia, no foro da consciência ${ }^{60}$. Apesar do seu carácter eminentemente oral, existem vestígios de que alguns gozaram desta

${ }^{58}$ Memoriaes para o S. Concil. Bracarense Provincial, que publicou o R.mo sôr Dom frey Bartholomeu dos Martires (1566), (ed. por A. do Rosário). Porto: Arquivo Histórico Dominicano Português; Movimento Bartolomeano, 1972, p. 2 (1 ${ }^{\text {a }}$ pt., cap. 7).

${ }^{59}$ Acerca dos privilégios de absolvição dos padres da Companhia ver MARCOCCI, Giuseppe - Inquisição, jesuítas e cristãos-novos em Portugal no século XVI. Revista de História das Ideias. 25 (2004) 247-326, sobretudo p. 256-259.

${ }^{60}$ Sobre a figura do penitenciário mor ver Concilium Provinciale Braccaren. IIII. Braccarae: Apud Antonium â Maris, 1567, fl. 49 (act. 2, caps. 19-20). Os casos reservados na arquidiocese permaneceram os catorze (o primeiro era a heresia) fixados pelas Constituições do arcebispado de Braga. Lisboa: por Germão Galharde, 1538, fl. 9rv. Em continuidade com uma posição já expressa em Trento (ver Concilium Tridentinum. Diariorum, Actorum, Epistolarum Nova Collectio. Friburgi Brisgoviae: Societas Görresiana, 1901, vol. 3, p. 539-550, cap. 4, §. 28), Bartolomeu dos Mártires opôs-se ao aumento dos casos reservados (Memoriaes..., cit., p. 32-33, 2a pt., cap. 48). Trata-se de uma diferença substancial em relação ao cardeal Carlo Borromeu (ver BRAMBILLA, Elena - Alle origini..., cit., p. 501, n. 16). Encaram o sistema judiciário da confissão, no contexto de Milão, BOSSY, John The social history of confession in the age of the Reformation [1975] (cito da tradução italiana in BOSSY, John - Dalla comunità all 'individuo. Per una storia sociale dei sacramenti nell'Europa moderna. Torino: Einaudi, 1998, p. 59-85: 70-72) e BOER, Wietse de - The Conquest of the Soul. Confession, discipline, and Public Order in Counter-Reformation Milan. Leiden: Brill, 2001, p. 212-257. 
solução doce, como deixam intuir os casos do suposto luterano Bartolomeu dos Banhos, ou do pregador diocesano Manuel Fernandes ${ }^{61}$.

Isto não significa que em Braga se desconfiasse do foro exterior. Pelo contrário. Nos primeiros anos pós-tridentinos, em que se registou, no Reino, um notável aumento do poder dos bispos em virtude do auxílio que o braço secular estaria obrigado a prestar-lhes (1564-69), houve um recurso intenso a inquéritos judiciais e processos, que se celebraram no Auditório Eclesiástico da cidade, um dos tribunais mais poderosos e menos estudados do Portugal moderno ${ }^{62}$. Entre 1565 e 1566 foi mesmo reforçada a capacidade do Auditório, com recurso a leigos, uma vez que os clérigos que havia já não eram suficientes para acudir às necessidades ${ }^{63}$. A perda das fontes judiciais limita o nosso conhecimento dos factos, mas há indícios que, além de se ocupar de graves pecados públicos, os magistrados da arquidiocese celebraram causas por bigamia, por sodomia, até por bruxaria (tema ao qual D. frei Bartolomeu dedicou um tratado, hoje perdido) e, talvez, por criptojudaísmo, sem nenhuma coordenação com o Santo Ofício. Entre os castigos aparecem o açoite, a prisão e a pena de sair em público com uma vela acesa na mão ${ }^{64}$. O que o arcebispo dominicano procurava era um espectáculo edificante de arrependimento e misericórdia, deixando entrever a futura recuperação do réu. No centro do poder eclesiástico dominava sempre a religião, mas ficava evidente a distância entre a justiça pastoral e a justiça das fogueiras.

Bartolomeu dos Mártires delineou o seu modelo de administração eclesiástica no quarto Concílio provincial (1566-67): de um lado, o domí-

${ }^{61}$ Livro da Visitação..., cit., p. 49-51.

${ }^{62}$ CAETANO, Marcelo - Recepção e execução dos decretos do Concílio de Trento em Portugal. Revista da Faculdade de Direito de Lisboa. 19 (1965) 7-87.

${ }^{63}$ Breve Exponi nobis, 6 de Agosto de 1565, in ADB - Caixa das Bulas, n. 7, doc. 194; provisão de Bartolomeu dos Mártires, 21 de Outubro de 1566, in ADB - Registo Geral, 390, fls. 90 ss., citado por CAPELA, José V. - A Relação Bracarense (séc. XV-1790). Apogeu e crise de uma singular instituição judiciária portuguesa. Bracara Augusta. 49 (2000) 175-214, principalmente p. 187.

${ }^{64}$ Sobre a extirpação da superstição ver também Concilium Provinciale ..., cit., fl. 121rv (act. 5, cap. 11). Exemplos de penitências públicas em SOARES, António Franquelim Sampaio Neiva - A Arquidiocese de Braga no século XVII. Sociedade e mentalidades pelas visitações pastorais (1550-1700). Braga: [s.n.], 1997, p. 644; Livro da Visitação..., cit., passim. 
nio capilar do território, através da coordenação entre agentes locais, chamados "síndicos" e "inquisidores", e os visitadores diocesanos, cujas funções foram esclarecidas nos decretos conciliares, concretizando-se num mecanismo que se acha magistralmente descrito numa página da biografia de D. frei Bartolomeu, redigida pelo confrade Luis de Granada; de outro lado, a penetração das consciências individuais, mediante o grande impulso dado aos confessores ${ }^{65}$. Se a visita devia ser a "alma do governo pastoral", como escreveu o arcebispo dominicano no seu Stimulus Pastorum (1565), no sacramento da penitência os fiéis podiam encontrar os remédios para as doenças do espírito, tal como recomendara frei Henrique de Távora, autor de um Tratado de Avisos de confessores (1560), escrito por mandado de Bartolomeu dos Mártires ${ }^{66}$.

Nesse sistema não se previu qualquer repressão indiscriminada dos cristãos-novos. A impressão que fica é que o arcebispo de Braga não teria uma oposição ideológica total contra os descendentes dos judeus ${ }^{67}$. Por exemplo, durante os anos 70, manteve uma estreita relação com o reitor do Colégio dos jesuítas, Cipriano Suárez, o qual, por ser cristão-novo, foi duramente contestado por outros padres da Companhia; da mesma maneira, quando o Conselho Geral do Santo Ofício pediu a D. frei Bartolomeu que nomeasse um visitador das naus em Viana do Castelo, ele escolheu um confrade que tinha origem judaica ${ }^{68}$. Por outro lado, entre os anos 70 e o início dos 80 , como já

${ }^{65}$ Sobre a rede territorial ver Concilium Provinciale..., cit., fl. 34v-39v (act. 2 , De Provisoribus \& Vicarijs Praelatorum); acerca do sistema da visitação, ver ibid., fs. 25v-31 (act. 2, De visitatione); 59v-60 (act. 3, De inquisitione morum \& examine assumendorum ad parrochiales ecclesias, cap. 1); GRANADA, Luis de - Vida de don fray Bartolomé de los Mártires..., cit., p. 183-184.

${ }^{66}$ MÁRTIRES, Bartolomeu dos - Stimulus Pastorum ex sanctorum floribus ardentoribusque verbis praecipue concitatus, (ed. por R. de Almeida Rolo). Braga: [s. n.], 1963, p. 139; TÁVORA, Henrique de, Tratado de Avisos de confessores... Coimbra: João de Barreira, 1560, cap. 11, Do confessor emquanto médico.

${ }^{67}$ Contudo, o empenho na procura de judaizantes nas visitas pastorais levou D. frei Bartolomeu a proibir visitadores cristãos-novos (ver Concilium Provinciale ..., cit., fl. 30v).

${ }^{68}$ Sobre o jesuíta Suárez ver MARCOCCI, Giuseppe - Inquisição, jesuitas..., cit., p. 285-286. A verdadeira condição do dominicano cristão-novo Francisco do Espírito Santo, nomeado visitador das naus por Bartolomeu dos Mártires em 1575 (ver ANTT - Conselho Geral do Santo Ofício, Livro 442, fl. 40v), foi denunciada em 1583 pelo arcebispo D. João Afonso de Meneses aos deputados do Conselho Geral (carta publicada em Índices dos livros proibidos em Portugal no século XVI (ed. por A. Moreira de Sá). Lisboa: INIC, 1983, doc. 40). 
foi assinalado acima, houve muito poucos súbditos da grande arquidiocese de Braga processados por criptojudaísmo na Inquisição de Coimbra ${ }^{69}$. De facto, o arcebispo não remetia de sua espontânea vontade aqueles casos para o Santo Ofício. E quando isto aconteceu, como no caso do castelhano Pedro de Villa Rubia, as autoridades episcopais actuaram com tal lentidão, que se fica na dúvida se nunca houve notícia no Auditório bracarense das denúncias contra o cristão-novo que os vigários de Chaves receberam durante anos (1563-70 $)^{70}$. Se este foi um caso exemplar da colaboração existente entre os agentes da justiça episcopal e a Inquisição, trata-se de um resultado modesto e bem diferente do que o Santo Ofício costumava então esperar da maioria dos bispos.

Talvez fosse por esta razão, que por volta da metade dos anos 70, com um procedimento absolutamente invulgar, o licenciado Jerónimo de Sousa, inquisidor de Évora desde 1571, foi transferido para Vila Flor, onde tinha tomado posse de abade da igreja de São Bartolomeu. À escolha não terá sido estranho o inquisidor geral D. Henrique, do qual o licenciado Sousa era criatura. Daquela posição encoberta, iniciou a manobrar contra a numerosa e irrequieta comunidade local de cristãos-novos, organizando inquéritos e recolhendo testemunhos de denúncia, com comissão do Santo Ofício de Coimbra. Assim, quando na Primavera de 1577 Bartolomeu dos Mártires e os seus oficiais chegaram a Vila Flor para a periódica visitação pastoral, encontraram um terreno já preparado para um ataque directo da Inquisição. Perante as culpas já reunidas por Sousa, o arcebispo não pôde senão transmitir ao Santo Ofício as denúncias recebidas pelos seus visitadores (contra Manuel Lopes, Isabel Lopes e sua filha Maria Álvares) ${ }^{71}$. Contudo, é sintomático que tenha consultado primeiro os desembargadores do Auditório Eclesiástico de Braga sobre tão delicado assunto. Aliás, o tom frio da carta enviada aos inquisidores de Coimbra, a 19 de Junho de 1577,

${ }^{69}$ Os sentenciados foram quase uma trintena, na maioria de Vila Flor; nenhum era da cidade de Braga (dados tirados de MEA, Elvira Cunha de Azevedo - Sentenças..., cit.)

${ }^{70}$ ANTT - Inquisição de Coimbra, Livro 288, fl. 437-442v. O Santo Ofício não chegou a abrir o processo.

${ }^{71}$ Assim consta pelas causas abertas contra Manuel Lopes (ANTT - Inquisição de Coimbra, proc. 458) e Isabel Lopes (ANTT - Inquisição de Coimbra, proc. 536). Maria Álvares tinha fugido para Castela. Agradeço a Maria Fernandes Guimarães a indicação destes processos. 
na qual D. frei Bartolomeu informou o Tribunal daqueles casos de heresia, revela todo o mal-estar com aquela subterrânea intrusão do Santo Ofício nos seus territórios ${ }^{72}$. De facto, foi mediante uma tal estratégia que a Inquisição conseguiu prender um grupo circunscrito, mas relevante de cristãos-novos de Vila Flor. Por fim, as irregularidades e as falsidades em que assentavam as acusações acabaram por limitar os efeitos daqueles processos ${ }^{73}$.

De qualquer maneira, não faltaram episódios de maior concerto, que ajudam a perceber a própria hierarquia de Bartolomeu dos Mártires no âmbito da vigilância sobre a ortodoxia. Em primeiro lugar estava a ameaça do luteranismo. Quando, em 1566, foi descoberto um herege flamengo em Chaves, o vigário geral da arquidiocese não hesitou em avisar imediatamente os inquisidores de Coimbra. Jan Rust veio a sair no auto da fé de 5 de

${ }^{72}$ Pelo seu teor, a carta merece ser transcrita: "Muito Reverendos Senhores, pax et vera consolatio. Visitando aguora neste mes de mayo proximo pasado a parrochial igreja de Sam Brás de Samões desta comarqua da Torre de Moncorvo, achey culpas pertencentes ao Santo Oficio contra hum Manuel Lopez cristão novo de Villa Frol, polas quaes o mandey prender e mandey o treslado delas aa minha Relaçam a quem escrevy as visem e me mandasem dizer o que se devia fazer açerqua do livramento deste homem, e os desembarguadores me responderam que imviase as ditas culpas a Vosas Merçes pera que elles provessem açerqua disso como lhes parecese serviço de Noso Senhor, polo qual mandey tresladar as ditas culpas autenticamente e vam tresladadas na verdade e fielmente, o qual traslado imvio a Vosas Merçes pera que o vejão e provejam açerqua deste neguoceo como lhes parecer serviço de Noso Senhor, e me farão charidade mandarme loguo a resposta por este portador que nam vay a outra cousa. Tambem visitando no dito mes de mayo Villa Frol sairão na visitaçam culpas contra Isabel Lopez e sua filha Maria Alvarez cristãs novas da dita vila, o traslado das quais culpas tambem imvio a Vosas Merçes, pera que tambem açerqua disso provejam como lhes parecer serviço de Deos. Nam se ofereçe mais senam que Noso Senhor os tenha sempre em sua guarda. Do luguar da Orta, aos 19 de Junho de 1577. Arcebispo Primaz”, ANTT Inquisição de Coimbra, proc. 458, fl. 3. Preso na cadeia do Santo Ofício a 4 de Agosto de 1577, Manuel Lopes acabou por ser absolvido e solto a 3 de Setembro de 1581.

${ }^{73}$ Os cristãos-novos envolvidos nas causas inquisitoriais tinham ramificações familiares com outros notáveis grupos de ascendência judaica residentes em localidades vizinhas. No episódio teve um papel de destaque um cristão-novo de Alfândega da Fé, António Nunes, condenado como falsário, em 1582, ver ANTT - Inquisição de Coimbra, proc. 3870. Em 1578 foram absolvidos Fernão Rodrigues (ANTT - Inquisição de Coimbra, proc. 4322) e Inês Lopes (ANTT - Inquisição de Coimbra, proc. 4568), cristãos-novos, de Vila Flor, ambos acusados por Nunes. Ao contrário, Isabel Lopes não escapou à abjuração de vehementi, em 1583 (processo cit. na nota 71), apesar da condenação se basear nos testemunhos singulares da filha Violante Álvares, também sentenciada naquele ano (ANTT - Inquisição de Coimbra, proc. 457), e do mesmo falsário Nunes. Além da mãe, Violante tinha acusado também a irmã Maria Álvares, ausente (ANTT - Inquisição de Coimbra, proc. 8765), actuando em colaboração com seu marido, o tabelião cristão-velho Gaspar da Rosa. 
Outubro de 1567, onde abjurou publicamente ${ }^{74}$. Mas nem sequer no caso de protestantismo a conduta de $\mathrm{D}$. frei Bartolomeu foi marcada pela prontidão em transmitir os culpados ao Santo Ofício. Antes de ser condenado à morte pela Inquisição de Lisboa (1574), o francês Jean de Lyon trabalhou durante anos ao serviço de António de Mariz, tipógrafo oficial do arcebispo, e teve relações de estreita amizade com um familiar de Bartolomeu dos Mártires, o clérigo Fernão Gonçalves Malheiro, o qual estava bem informado das erróneas opiniões religiosas do estrangeiro. Contudo, nem o arcebispo, nem qualquer dos seus oficiais jamais escreveram uma só linha ao Santo Ofício para denunciar aquele caso escandaloso ${ }^{75}$. Finalmente, também se olharmos para outros tipos de delitos, não se encontram provas significativas de um sistema judiciário pronto a reconhecer a superioridade da Inquisição. Por exemplo, o médico polígamo Gaspar de Faria teve que casar cinco vezes e encarar denúncias e processos no Auditório eclesiástico de Braga, antes que o seu caso fosse transferido para os juízes do Santo Ofício ${ }^{76}$.

\section{Notas conclusivas}

A inquisição pastoral de Bartolomeu dos Mártires espera ainda um estudo aprofundado. O seu fundamento parece ter sido uma visão alternativa do modo de proceder para enfrentar a presença da heresia; a sua existência tornou-se possível pela defesa da autonomia jurisdicional de que o arcebispo e senhor de Braga gozava por tradição imemorial. Não houve um confronto aberto entre o Santo Ofício e D. frei Bartolomeu, o qual, em público, se manteve sempre respeitoso da autoridade formal da Inquisição ${ }^{77}$. Isto não quer dizer que ele tenha concordado com os métodos dos inquisidores, nem que lhes tenha oferecido uma sistemática colaboração. É um facto que os agentes do Tribunal da Fé não entraram no vasto território bracarense, senão por pedido, ou com licença, do arcebispo.

\footnotetext{
${ }^{74}$ ANTT - Inquisição de Coimbra, proc. 934.

${ }^{75}$ ANTT - Inquisição de Lisboa, proc. 1366.

${ }^{76}$ ANTT - Inquisição de Coimbra, proc. 5005.

${ }^{77}$ Memoriaes..., cit., p. 12 (cap. 84).
} 
Tudo parece apontar na direcção de que o sistema criado por Bartolomeu dos Mártires tenha sido um exemplo concreto do que Foucault chamou "poder pastoral". Aquele modelo de justiça e de vigilância das ideias e dos comportamentos teve a sua eficácia. Além disso, pelo uso frequente de soluções inclinadas à misericórdia, o seu impacto na sociedade foi menos dilacerante do que a Inquisição, a qual, na mesma altura, perseguia com violência centenas de cristãos-novos no Reino ${ }^{78}$. Está aqui, no meu ver, a razão de uma proposta só aparentemente contraditória, avançada pelo cardeal infante D. Henrique em 1574. Naquela altura, o ancião príncipe inquisidor era um homem politicamente bastante isolado. Tinha-se retirado para Alcobaça, onde meditava sobre a morte já próxima e sobre o que ia deixar em herança. Pensava também no seu sucessor na condução do Santo Ofício. Ao jovem rei D. Sebastião, que governava num clima cada dia mais tenso, em que dominavam os jesuítas da corrente mais intransigente e segregacionista, já adversos ao cardeal infante, este último propôs a figura de D. frei Bartolomeu como seu substituto. Tratava-se claramente de uma solução de compromisso. Mas das expressões do inquisidor geral emerge também a admiração face ao prelado dominicano: "tem feito já muito no arcebispado"; "de outra maneira não se poderá ter uma pessoa e de justiça destas qualidades". Atente-se nas palavras. O "muito" eram os resultados conseguidos pelo arcebispo de Braga através de uma vigilância religiosa que não provocava fracturas. A "justiça” era o seu sistema de inquisição pastoral, que podia dar maior garantia de ordem social, numa época de ásperas controvérsias, que explodiriam na crise dinástica de $1580^{79}$.

Como poderia ter mudado o Santo Ofício nas mãos de Bartolomeu dos Mártires é pergunta destinada a ficar sem resposta. Não se sabe se ele chegou a ter notícia da proposta do cardeal infante. O certo é que a evolução, nos anos seguintes, desaconselhou a manutenção daquela hipótese. Os acontecimentos que levaram à concessão de uma nova isenção do confisco dos bens para os cristãos-novos condenados pela Inquisição (1577) reafirmaram, na opinião

${ }^{78}$ Um estudo dos efeitos prolongados das prisões numa comunidade em PAIVA, José Pedro - As entradas da Inquisição, na vila de Melo, no século XVII: pânico, integração/segregação, crenças e desagregação social. Revista de História das Ideias. 25 (2004) 169-208.

${ }^{79}$ Carta do cardeal infante D. Henrique ao rei D. Sebastião, Alcobaça, 9 de Julho de 1574, publicada em PEREIRA, Isaías da Rosa - Documentos..., cit., p. 131-132. 
de D. Henrique, a necessidade de uma acção dura e implacável contra os suspeitos judaizantes. A crise dinástica que se abriu no ano seguinte, pela morte em África de D. Sebastião, deixou evidente a exigência de um poder político sólido. O inquisidor geral tornou-se rei. Já não se podia presumir um sucessor no governo do Santo Ofício que não insistisse num modelo tradicional, o qual, nas décadas anteriores, tinha sido um essencial ponto de referência na definição da identidade católica do Reino.

Foi assim que, em 1579, tomou posse do cargo de inquisidor geral D. Jorge de Almeida, enquanto Bartolomeu dos Mártires permaneceu sentado na cadeira de arcebispo de Braga. Em Portugal já não havia espaço para uma inquisição pastoral. Não foi por acaso que, logo a seguir à renúncia do arcebispado por parte de D. frei Bartolomeu, em 1582, foi organizada uma visita inquisitorial nos territórios do Norte, confiada ao responsável das prisões de Vila Flor, o licenciado Jerónimo de Sousa ${ }^{80}$. Mas quando o insidioso visitador começou a andar pelas localidades de Trás-os-Montes, encontrou a surda resistência dos cristãos-novos, acostumados a resolver os seus erros de outra forma, no espaço protegido da consciência. Era este o subentendido de uma petição que os habitantes de origem judaica de Torre de Moncorvo apresentaram ao Santo Ofício. Protestando contra a injustiça das capturas provocadas pelo licenciado Sousa, não acharam argumento mais válido para demonstrar a sua ortodoxia, do que a garantia oferecida pelas sistemáticas visitas pastorais do arcebispo Bartolomeu dos Mártires e dos seus agentes, que nunca tinham originado processos ${ }^{81}$. Mas aquela era uma outra inquisição: era a inquisição pastoral, que tinha vigorado na arquidiocese de Braga durante os vinte anos anteriores. Já pertencia ao passado. Contudo, a memória da desconfiança no estilo do Santo Ofício

${ }^{80}$ Os documentos relativos à visita inquisitorial encontram-se em ANTT - Inquisição de Coimbra, Livros 662; 286. A comparação entre as assinaturas confirma que se tratava da mesma pessoa que anteriormente tinha sido inquisidor de Évora e depois abade da igreja de São Bartolomeu de Vila Flor. Além disso, a identidade entre o antigo inquisidor e o visitador acha-se declarada num parecer do Conselho Geral, de 7 de Dezembro de 1591: "no anno de 82 visitou a comarca de Traslosmontes o licenciado Hieronymo de Sousa inquisidor que foi da cidade d'Evora", ver ANTT - Conselho Geral do Santo Ofício, Livro 92, fl. 36.

${ }^{81} \mathrm{O}$ memorial dos cristãos-novos acha-se publicado na íntegra em MEA, Elvira Cunha de Azevedo - O procedimento inquisitorial..., cit., p. 89-95. Toda a visita merece um novo estudo à luz do papel excepcional do licenciado Jerónimo de Sousa. 
por parte do promotor deste modelo alternativo estava destinada a deixar rastos para o futuro ${ }^{82}$.

${ }^{82}$ Encontra-se referência à desconfiança de Bartolomeu dos Mártires nos métodos do Santo Ofício nos três volumes do processo de beatificação, na Congregação dos Ritos, publicados em Roma, pela tipografia da Câmara Apostólica entre 1804 e 1840. 